\title{
Review Paper: Balance in the Blind: A Systematic Review
}

\author{
Hassan Daneshmandi ${ }^{1}$ (D, Ali Asghar Norasteh ${ }^{1}$ (D), Hamed Zarei ${ }^{{ }^{*}}$ (C)
}

1. Department of Corrective Exercise and Sport Injuries, Faculty of Physical Education and Sports Sciences, University of Guilan, Rasht, Iran.

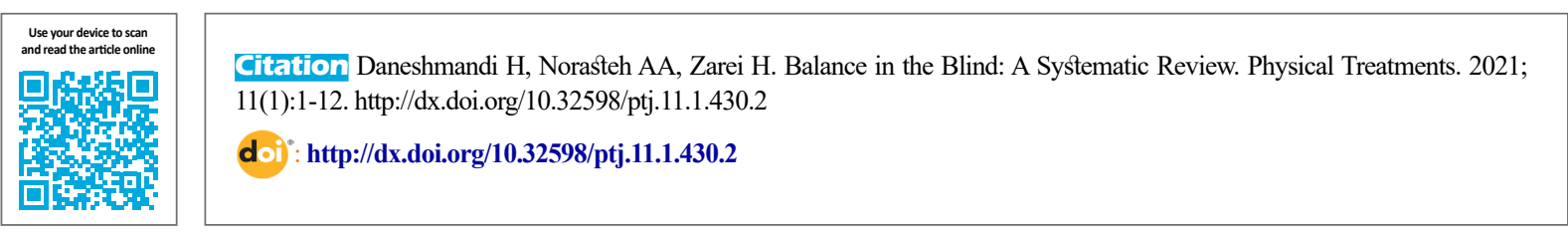

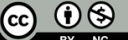

Article info:

Received: 16 Feb 2020

Accepted: 3 Mar 2020

Available Online: 01 Jan 2021

Keywords:

Blind balance, Posture control, Visual impairment, Balance, Blind

\section{A B S T RA C T \\ Purpose: This paper reviews the studies on balance in the blind.}

Methods: The paper comprehensively reviewed studies on balance in the blind from the following databases: PubMed, MEDLINE, Web of Science, ScienceDirect, Cochrane Central Register of Controlled Clinical Trials, Google Scholar, and Scopus, from 2001 to 2019. Also, other available papers were examined.

Results: Out of 35 evaluated studies, 32 articles were fully represented and the rest were only summarized. These articles covered two issues: 1) balance adaptation in the blind, 2) the effects of training protocols on the balance in the blind.

Conclusion: The blind suffer from poor balance. However, they tend not to differ from normal people, when sufficient data from the vestibular and proprioception systems are available. Also, balance in the blind improves by age, which increases the efficiency and maturity of vestibular and proprioception systems. The blind tend to be more reliant on the hip than ankle strategy. All the training protocols reviewed in this paper have positively affected balance in the blind. Nevertheless, it was impossible to determine the most efficient protocol, and further qualitative studies are required for this purpose.

\footnotetext{
* Corresponding Author:

Hamed Zarei, PhD. Cndidate

Address: Department of Corrective Exercise and Sport Injuries, Faculty of Physical Education and Sports Sciences, University of Guilan, Rasht, Iran.

Phone: +98 (939) 5995280

E-mail: zareei.h@yahoo.com
} 


\section{Highlights}

- A comprehensive review of the literature showed poor balance in the blind.

- Considering vestibular and proprioception inputs, the blind showed similar performance as that of sighted subjects.

- Balance in the blind improved by age because of the development of vestibular and proprioception systems.

- The blind mostly rely on the hip strategy.

- All training protocols and exercises were found to have positive effects on balance in the blind.

\section{Plain Language Summary}

It was found that the blind suffer from poor balance. However, they tend to be no different from normal people when sufficient data from vestibular and proprioception systems are available. It was also found that balance in the blind improves by age that increases the efficiency and maturity of vestibular and proprioception systems. The blind tend to be more reliant on hip than ankle strategy. All the training protocols reviewed in this paper have positively affected balance in the blind.

\section{Introduction}

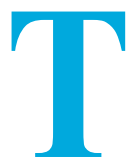

he key nervous components of postural control include motor processes, such as neuromuscular synergies, and sensory processes, such as visual, vestibular, and proprioception systems $[1,2]$. The vestibular receivers play a significant role in basic motion responses (maintaining head and posture) as they receive input related to the position of the head in space and generating reflexes [3]. Moreover, the somatosensory system provides information on the body's periphery and helps to realize the signals of pain, heat, touch, and proprioception. The visual system collects information about external body position [4]. Postural control occurs when the relationship between sensory input and appropriate motion responses, such as efficient muscular strength is established [5]. Besides, the poor performance of postural control occurs when one of these systems is impaired [6].

The visual system provides immediate information about the environment to the nervous system and plays an essential role in establishing balance [7]. Visual input acts as a significant sensory source for postural states [8]. Thus, any sort of visual impairment is directly related to movement dysfunction and balance instability and negatively affects static and dynamic balance [7]. Blind people received fewer motion pattern signals in the central nervous system and had lower balance performance, compared with normal people [9]. In this regard, exer- cise improves and integrates postural control in the central nervous system [10]. The current paper seeks to answer the following questions: does training intervention improve balance in the blind? What are effective control mechanisms to improve balance in the blind? What are the most effective training protocols? In the absence of visual input, do other sensory systems help to maintain balance in the blind?

\section{Materials and Methods}

The present study comprehensively reviewed balance in the blind from databases, including Embase, ScienceDirect, PubMed, CINAHL, Google Scholar, MAGIRAN, IRANDOC, IranMedex, MedLib, and SID. It also covered a 19-year duration from 2001 to 2019 and used the combination of the following keywords: blindness/ acquired blindness/congenital blindness $\times$ visual disorder/visually impaired person $\times$ postural control/balance. Also, the search was restricted to filters, such as English language, Persian language, human, original article, and review article. Initially, the title and summary of the resulting articles were carefully studied and those that did not meet the inclusion criteria were excluded from analysis. Inclusion criteria were study on blind population, articles in Persian or English, evaluation for balance in the blind, and the clear analysis of balance. Finally, a total number of 35 articles were obtained. 


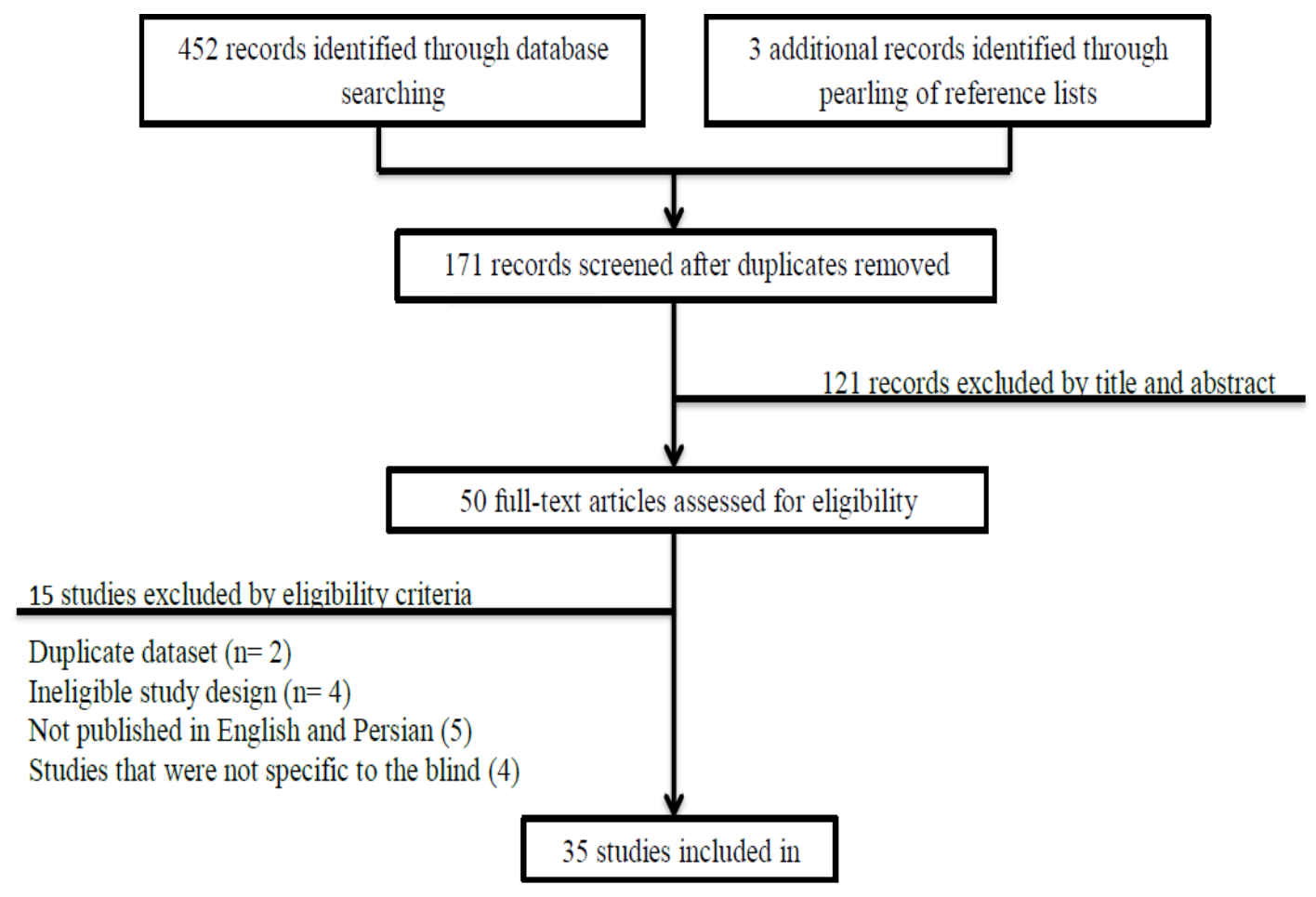

Figure 1. Flowchart for the screening of articles

\section{Results}

Figure 1 shows the selection process of the study. The search resulted in a total number of 452 articles. Moreover, three more articles were obtained from manual searching. However, the irrelevant articles were excluded, and overall, 171 abstracts were studied. Next, 121 articles were eliminated from the study, and only 50 candidate articles were chosen for full examination. Out of the candidate articles, only 35 were selected for final examination to check for: 1) balance adaptation in the blind (Table 1 and 2) the effects of training protocols on balance in the blind (Table 2).

Ray et al. studied the effects of visual impairment on postural control and the balance strategy in the blind and reported significant differences in balance scores for people in challenging situations. These authors also showed that the blind mostly rely on hip strategy [9]. Salari et al. studied balance recovery strategies, manipulating the somatosensory, visual, and vestibular systems in healthy and blind populations. The results indicated that the healthy population had a significantly different average hip and ankle sway and showed greater anterior-posterior as well as posterior-anterior perturbations. These authors also reported that the hip-to-ankle fluctuation rate (dominant strategy for balance recovery) significantly differed in all positions. Their results indicated that both groups applied abrupt anterior-posterior and posterior-anterior perturbations for balance recovery, and then, showed different mechanisms and impulses. The blind used hip strategy for balance recovery but relied on somatosensory input as a superior balance system [11].

Nakata et al. examined automatic postural responses in subjects with congenital blindness and found that the electromyography activity of gastrocnemius muscle in the blind was lower than in their healthy counterparts. However, in response to the disorder, no delay was observed in the initiating electromyography activity of the lower extremity with closed or open eyes. Moreover, the blind showed greater agility than healthy participants to respond to the sensory-motor stimuli created by platform movement, but the two groups did not differ in upward or downward finger rotation. The same muscular activation delay and reflection time in the two groups indicate that congenital blindness does not affect spinal tensile reflex, however, it may affect the voluntary performance of the cortex. Also, the two groups did not significantly differ in the average fluctuation score of postural control with open or closed eyes, though the blind group showed greater fluctuation after backward transfer with open eyes. These results show that congenital blindness does not affect postural sway control in response to the disorder [12]. Horvat et al. studied isokinetic peak force and strength in visually impaired and blind adults. The 
Table 1. Results of balance adaptation studies in the blind

\begin{tabular}{|c|c|c|c|c|c|c|}
\hline Authors & PEDro Scale & Article Title & Sample Size & Age (y) Range & Measured Variables & Instrument \\
\hline $\begin{array}{l}\text { Ray et al. } \\
\text { [9] }\end{array}$ & 8 & $\begin{array}{l}\text { The impact of vision loss on } \\
\text { postural stability and balance } \\
\text { strategies in individuals with } \\
\text { profound vision loss }\end{array}$ & $\begin{array}{l}\text { Control group }=23 \\
\text { Experimental } \\
\text { group }=25\end{array}$ & $\begin{array}{l}\text { Control } \\
\text { group }=38.2 \pm 14.42 \\
\text { Experimental } \\
\text { group }=39.8 \pm 14.38\end{array}$ & $\begin{array}{l}\text { Balance and balance } \\
\text { recovery strategy }\end{array}$ & $\begin{array}{c}\text { NeuroCom } \\
\text { EquiTest System }\end{array}$ \\
\hline $\begin{array}{l}\text { Salari et al. } \\
\quad[11]\end{array}$ & 4 & $\begin{array}{l}\text { Assessment of balance } \\
\text { recovery strategies during ma- } \\
\text { nipulation of somatosensory, } \\
\text { vision, and vestibular system } \\
\text { in healthy and blind women }\end{array}$ & $\begin{array}{l}\text { Control group }=30 \\
\text { Experimental } \\
\text { group }=30\end{array}$ & 27 to 36 & $\begin{array}{c}\text { Balance recovery } \\
\text { strategy }\end{array}$ & $\begin{array}{l}\text { Biodex device and } \\
\text { Y balance test }\end{array}$ \\
\hline $\begin{array}{l}\text { Nakata } \\
\text { et al. } \\
\text { [12] }\end{array}$ & 7 & $\begin{array}{l}\text { Automatic postural response } \\
\text { systems in individuals with } \\
\text { congenital total blindness }\end{array}$ & $\begin{array}{l}\text { Control group }=9 \\
\text { Experimental } \\
\text { group }=9\end{array}$ & $\begin{array}{l}\text { Control group }=19 \\
\text { to } 24 \\
\text { Experimental } \\
\text { group }=19 \text { to } 24\end{array}$ & Posture control & $\begin{array}{l}\text { Force platform } \\
\text { and EMG }\end{array}$ \\
\hline $\begin{array}{l}\text { Horvat } \\
\text { et al. } \\
\text { [13] }\end{array}$ & 6 & $\begin{array}{l}\text { Comparison of isokinetic peak } \\
\text { force and power in adults with } \\
\text { partial and total blindness }\end{array}$ & $\begin{array}{l}\text { Control group }=12 \\
\text { Experimental } \\
\text { group }=12\end{array}$ & $\begin{array}{c}\text { Control } \\
\text { group }=35.1 \pm 13.4 \\
\text { Experimental } \\
\text { group }=36.2 \pm 13.2\end{array}$ & Posture control & $\begin{array}{l}\text { HUMAC-NORM } \\
\text { isokinetic dyna- } \\
\text { mometer }\end{array}$ \\
\hline $\begin{array}{l}\text { Ray et al. } \\
\text { [14] }\end{array}$ & 5 & $\begin{array}{l}\text { Clinical assessment of func- } \\
\text { tional movement in adults } \\
\text { with visualimpairments }\end{array}$ & $\begin{array}{l}\text { Visual impairment } \\
\text { group }=9 \\
\text { Blind group }=9\end{array}$ & 20 to 58 & Functional balance & $\begin{array}{l}\text { Timed up-and-go } \\
\text { and } 30 \text {-second } \\
\text { sit-to-stand }\end{array}$ \\
\hline $\begin{array}{l}\text { Giagazo- } \\
\text { glou et al. } \\
\text { [15] }\end{array}$ & 5 & $\begin{array}{l}\text { Static balance control and } \\
\text { lower limb strength in blind } \\
\text { and sighted women }\end{array}$ & $\begin{array}{l}\text { Control group }=10 \\
\text { Experimental } \\
\text { group }=10\end{array}$ & $\begin{array}{c}\text { Control } \\
\text { group }=33.5 \pm 8.3 \\
\text { Experimental } \\
\text { group }=33.5 \pm 7.9\end{array}$ & $\begin{array}{l}\text { Examining the iso- } \\
\text { kinetic and isometric } \\
\text { strength of the knee } \\
\text { and ankle muscles } \\
\text { and comparing the } \\
\text { center of pressure }\end{array}$ & $\begin{array}{l}\text { Force platforms } \\
\text { and the CoP } \\
\text { variations, Cybex } \\
\text { dynamometer }\end{array}$ \\
\hline $\begin{array}{l}\text { Aydog et al. } \\
\quad[16]\end{array}$ & 5 & $\begin{array}{l}\text { Dynamic postural stability in } \\
\text { blind athletes }\end{array}$ & $\begin{array}{l}\text { Sighted group }=20 \\
\text { Goalball players } \\
\text { group }=20 \\
\text { Blind sedentary } \\
\text { group }=20\end{array}$ & $\begin{array}{c}\text { Sighted } \\
\text { group }=24.67 \pm 5.82 \\
\text { Goalball players } \\
\text { group }=24.9 \pm 4.29 \\
\text { Blind sedentary } \\
\text { group }=26.24 \pm 4.26\end{array}$ & Posture control & $\begin{array}{l}\text { Biodex Stability } \\
\text { System }\end{array}$ \\
\hline $\begin{array}{l}\text { Tomomitsu } \\
\text { et al. [17] }\end{array}$ & 4 & $\begin{array}{c}\text { Static and dynamic pos- } \\
\text { tural control in low-vision and } \\
\text { normal-vision adults }\end{array}$ & $\begin{array}{l}\text { Control group }=25 \\
\text { Experimental } \\
\text { group }=25\end{array}$ & $\begin{array}{l}\text { Control } \\
\text { group }=26.1 \pm 4 \\
\text { Experimental } \\
\text { group }=28.6 \pm 6\end{array}$ & $\begin{array}{c}\text { Static and dynamic } \\
\text { balance }\end{array}$ & Functional tests \\
\hline $\begin{array}{l}\text { Müürsepp } \\
\text { et al. [18] }\end{array}$ & 7 & $\begin{array}{l}\text { Impact of visual impair- } \\
\text { ment on static and dynamic } \\
\text { postural control and habitual } \\
\text { physical activity in children } \\
\text { aged } 10-16 \text { years }\end{array}$ & $\begin{array}{l}\text { Control group }=13 \\
\text { Experimental } \\
\text { group }=13\end{array}$ & 10 to 16 & Posture control & Platform Kistler \\
\hline $\begin{array}{l}\text { Häkkinen } \\
\text { et al. [19] }\end{array}$ & 8 & $\begin{array}{c}\text { Neuromuscular function and } \\
\text { balance of prepubertal and } \\
\text { pubertal } \\
\text { blind and sighted boys }\end{array}$ & $\begin{array}{l}\text { Blind group before } \\
\text { puberty }=8 \\
\text { Blind group after } \\
\text { puberty }=8\end{array}$ & $\begin{array}{l}\text { Blind group before } \\
\text { puberty=9 to } 13 \\
\text { Blind group after } \\
\text { puberty=15 to } 18\end{array}$ & $\begin{array}{l}\text { Muscle mass thick- } \\
\text { ness, electromyog- } \\
\text { raphy and maximal } \\
\text { isometric strength, } \\
\text { dynamic explosive } \\
\text { actions, and balance }\end{array}$ & $\begin{array}{l}\text { Isokinetic dyna- } \\
\text { mometer, force } \\
\text { platform, and } \\
\text { EMG }\end{array}$ \\
\hline $\begin{array}{l}\text { Rutkowska } \\
\text { et al. [20] }\end{array}$ & 6 & $\begin{array}{l}\text { A comparison of body bal- } \\
\text { ance of blind children aged } \\
7-16 \text { years in sex and age } \\
\text { categories }\end{array}$ & $\begin{array}{l}\text { Blind children } \\
\text { group }=27 \\
\text { Blind teen } \\
\text { group }=33\end{array}$ & $\begin{array}{l}\text { Blind children } \\
\text { group }=6 \text { to } 11 \\
\text { Blind teen group }=12 \\
\text { to } 17\end{array}$ & Body balance & $\begin{array}{l}\text { Stabilographic } \\
\text { platform }\end{array}$ \\
\hline $\begin{array}{l}\text { Barati et al. } \\
\quad[21]\end{array}$ & 6 & $\begin{array}{l}\text { The growth status of bal- } \\
\text { ance capabilities of Visually } \\
\text { impaired children, blind and } \\
\text { their healthy counterparts }\end{array}$ & $\begin{array}{l}\text { Visual impairment } \\
\text { group }=30 \\
\text { Blind group }=16 \\
\text { Healthy group }=65\end{array}$ & 8 to 12 & $\begin{array}{l}\text { Static and dynamic } \\
\text { balance }\end{array}$ & $\begin{array}{c}\text { Static } \\
\text { balance=Romberg } \\
\text { test } \\
\text { Dynamic } \\
\text { balance=balance } \\
\text { board test }\end{array}$ \\
\hline $\begin{array}{l}\text { Rutkowska } \\
\text { et al. [22] }\end{array}$ & 8 & $\begin{array}{l}\text { Balance functional assess- } \\
\text { ment } \\
\text { in people with visual impair- } \\
\text { ment }\end{array}$ & $\begin{array}{l}\text { Blind children } \\
\text { group }=56 \\
\text { Blind teen } \\
\text { group }=71\end{array}$ & $\begin{array}{c}\text { Blind children } \\
\text { group= } 6 \text { to } 11 \\
\text { Blind teen group }=12 \\
\text { to } 16\end{array}$ & Functional balance & $\begin{array}{l}\text { Bruininks-Oser- } \\
\text { etsky test }\end{array}$ \\
\hline $\begin{array}{l}\text { Melzer } \\
\text { et al. } \\
\text { [23] }\end{array}$ & 9 & $\begin{array}{l}\text { The influence of an auditory- } \\
\text { memory attention-demanding } \\
\text { task on postural control in } \\
\text { blind persons }\end{array}$ & $\begin{array}{l}\text { Control group }=9 \\
\text { Experimental } \\
\text { group }=9\end{array}$ & $\begin{array}{c}\text { Control } \\
\text { group }=46.9 \pm 12.9 \\
\text { Experimental } \\
\text { group }=47.8 \pm 12.9\end{array}$ & Postural control & $\begin{array}{l}\text { Force } \\
\text { platform }\end{array}$ \\
\hline
\end{tabular}




\begin{tabular}{|c|c|c|c|c|c|c|}
\hline Authors & PEDro Scale & Article Title & Sample Size & Age (y) Range & Measured Variables & Instrument \\
\hline $\begin{array}{l}\text { Ozdemir et } \\
\text { al. [24] }\end{array}$ & 8 & $\begin{array}{l}\text { Sensorimotor posture control } \\
\text { in the blind: Superior ankle } \\
\text { proprioceptive acuity does } \\
\text { not compensate for vision loss }\end{array}$ & $\begin{array}{l}\text { Control group }=15 \\
\text { Experimental } \\
\text { group }=13\end{array}$ & $\begin{array}{l}\text { Control group }=20 \\
\text { to } 65 \\
\text { Experimental } \\
\text { group }=25 \text { to } 58\end{array}$ & Postural control & $\begin{array}{c}\text { Force } \\
\text { platform }\end{array}$ \\
\hline $\begin{array}{l}\text { Schmid et } \\
\text { al. [25] }\end{array}$ & 7 & $\begin{array}{l}\text { Equilibrium during static } \\
\text { and dynamic tasks in blind } \\
\text { subjects: no evidence of } \\
\text { cross-modal plasticity }\end{array}$ & $\begin{array}{l}\text { Control group }=25 \\
\text { Experimental } \\
\text { group }=25\end{array}$ & $\begin{array}{c}\text { Control } \\
\text { group }=36 \pm 13.5 \\
\text { Experimental } \\
\text { group }=43 \pm 5.9\end{array}$ & Postural control & $\begin{array}{c}\text { Force } \\
\text { platform }\end{array}$ \\
\hline $\begin{array}{l}\text { Shomeil } \\
\text { Shushtary } \\
\text { et al. [26] }\end{array}$ & 6 & $\begin{array}{l}\text { Vestibular-evoked myogenic } \\
\text { potential in congenitally blind } \\
\text { patients versus normal } \\
\text { subjects }\end{array}$ & $\begin{array}{l}\text { Control group }=20 \\
\text { Experimental } \\
\text { group }=20\end{array}$ & $\begin{array}{c}\text { Control } \\
\text { group }=21.95 \pm 2.16 \\
\text { Experimental } \\
\text { group }=22.5 \pm 2.83\end{array}$ & $\begin{array}{l}\text { Vestibular-evoked } \\
\text { myogenic potential }\end{array}$ & $\begin{array}{l}\text { Tone burst } \\
\text { stimulus }\end{array}$ \\
\hline $\begin{array}{l}\text { Farsi et al. } \\
\text { [27] }\end{array}$ & 5 & $\begin{array}{l}\text { Dual-task effects in sensory } \\
\text { systems interference condi- } \\
\text { tion on blind and sighted } \\
\text { persons balance }\end{array}$ & $\begin{array}{l}\text { Control group }=12 \\
\text { Experimental } \\
\text { group }=12\end{array}$ & $\begin{array}{c}\text { Control } \\
\text { group }=22.67 \pm 5.33 \\
\text { Experimental } \\
\text { group }=25.08 \pm 4.68\end{array}$ & Postural control & $\begin{array}{c}\text { Biodex Stability } \\
\text { System }\end{array}$ \\
\hline $\begin{array}{l}\text { Moham- } \\
\text { madi et al. } \\
{[28]}\end{array}$ & 6 & $\begin{array}{l}\text { Better functioning of the } \\
\text { somatosensory system in pos- } \\
\text { tural control of blind athletes } \\
\text { compared to non-athletes }\end{array}$ & $\begin{array}{l}\text { Nonathlete vision } \\
\text { group }=10 \\
\text { Nonathlete blind } \\
\text { group }=10 \\
\text { Blind athlete } \\
\text { group }=10\end{array}$ & $\begin{array}{c}\text { Nonathlete vision } \\
\text { group }=18.20 \pm 1.47 \\
\text { Nonathlete blind } \\
\text { group }=18.70 \pm 1.13 \\
\text { Blind athlete } \\
\text { group }=19.20 \pm 1.13\end{array}$ & Postural control & $\begin{array}{c}\text { Biodex Stability } \\
\text { System }\end{array}$ \\
\hline
\end{tabular}

PHYSICAL TREA TMENTS

results showed that the subjects had better physical performance at low speed. Besides, gender differences were observed in both groups, but the groups did not significantly differ. Their results indicate that physical performance is similarly impaired in visually impaired and blind people [13]. Ray et al. performed a clinical analysis of the functional performance of visually impaired people and reported lower balance and strength indexes [14]. Furthermore, Giagazoglou et al. studied the isometric and isokinetic power of ankle and hip muscles in female and male blind and sighted subjects. They found that anterior-posterior and interior-exterior balance controls were better in sighted than in blind subjects. However, no significant difference was found between the study groups, in closed eye conditions. Considering the isometric and concentric power of the muscles of the lower extremity, it was asserted that the blind had a poor performance in balance tests [15].

Aydog et al. compared dynamic posture stability between blind athletes, normal people, and inactive blinds. They realized that the blind generally had poor balance, but blind athletes showed greater balance than inactive blinds [16]. Tomomitsu et al. studied static and dynamic balance in visually impaired and normal people and reported that visually impaired subjects had lower postural stability in dynamic tests and soft surfaces. Moreover, visual feedback was more important for them to determine balance [17]. Müürsepp et al. selected 13 normal and 13 visually impaired children to investigate the effects of visual disorder on postural control with open and closed eyes. They found no difference in postural control with closed eyes, but normal children showed significantly greater postural control with open eyes [18].

Häkkinen et al. studied neuromuscular performance in blind subjects before and after puberty, as compared with normal people. These authors found no significant difference in the muscle mass volume, maximum muscular strength, and vertical jump. Moreover, the blind showed poorer single-foot balance, before puberty. Disregarding the vision, the blind and normal people do not differ from each other [19]. Rutkowska et al. examined the effects of gender and age on balance in the blind and reported no difference between male and female blind subjects and for the age groups of 7 to 11 years and 12 to 16 years [20]. Ahmadi Barati et al. studied the growth status of the balance capabilities of visually impaired and blind children and their healthy counterparts (age range, 8-12 years). The results showed a significant difference in balance capabilities between visually impaired and healthy children [21]. Also, Rutkowska et al. studied balance in visually impaired subjects, based on the Bruininks-Oseretsky test of motor proficiency second edition (BOT ${ }^{\mathrm{TM}_{-}}$2). These researchers tried to figure out the highest balance disorder in terms of vision loss and the age of blindness. They used 127 subjects (66 visually impaired and 61 healthy), including 68 females and 59 males in the age range of 6 to 16 years. They used the Bruininks-Oseretsky test of motor proficiency to measure static balance and found that gender played no role in maintaining balance but the age and intensity of blindness significantly affected balance. Besides, the lowest level of balance was observed in the age group of 7 to 11 years. It is needed to develop physical fitness pro- 
Table 2. Results of the study on the effect of training protocols on the balance of the blind

\begin{tabular}{|c|c|c|c|c|c|c|c|}
\hline Authors & PEDro Scale & Article Title & Sample Size & Age (y) Range & $\begin{array}{c}\text { Mea- } \\
\text { sured } \\
\text { Variables }\end{array}$ & Instrument & Main Results \\
\hline $\begin{array}{l}\text { Jazi et al. } \\
\text { [29] }\end{array}$ & 4 & $\begin{array}{l}\text { Effect of selected } \\
\text { balance exercises on } \\
\text { the dynamic balance } \\
\text { of children with } \\
\text { visual impairments }\end{array}$ & $\begin{array}{l}\text { Control } \\
\text { group }=9 \\
\text { Experimen- } \\
\text { tal group=10 }\end{array}$ & 8 to 14 & $\begin{array}{l}\text { Func- } \\
\text { tional } \\
\text { balance }\end{array}$ & BESS test & $\begin{array}{l}\text { Results showed sig- } \\
\text { nificant improvements } \\
\text { in the balance of the } \\
\text { experimental group } \\
\text { after an eight-week } \\
\text { training protocol. }\end{array}$ \\
\hline $\begin{array}{l}\text { Sajjadi } \\
\text { Manizani } \\
{[30]}\end{array}$ & 5 & $\begin{array}{l}\text { The effect of four } \\
\text { weeks of treadmill } \\
\text { training on static and } \\
\text { dynamic balance of } \\
\text { the blind and visually } \\
\text { impaired }\end{array}$ & $\begin{array}{l}\text { Control } \\
\text { group=13 } \\
\text { Experimen- } \\
\text { tal group=13 }\end{array}$ & $11.16 \pm 1.69$ & $\begin{array}{l}\text { Static } \\
\text { balance } \\
\text { and } \\
\text { dynamic } \\
\text { balance }\end{array}$ & $\begin{array}{c}\text { Static balance }=\text { stork } \\
\text { test } \\
\text { Dynamic balance }=Y \\
\text { test }\end{array}$ & $\begin{array}{l}\text { Training with a } \\
\text { treadmill on a smooth } \\
\text { and sloping surface } \\
\text { improves static and } \\
\text { dynamic balance in } \\
\text { visually-impaired } \\
\text { people. }\end{array}$ \\
\hline $\begin{array}{l}\text { Mavro- } \\
\text { vouniotis } \\
\text { et al. [31] }\end{array}$ & 4 & $\begin{array}{l}\text { The effect of a } \\
\text { combined training } \\
\text { program with Greek } \\
\text { dances and Pilates } \\
\text { on the balance of } \\
\text { blind children }\end{array}$ & $\begin{array}{c}\text { Control } \\
\text { group }=5 \\
\text { Experimen- } \\
\text { tal group }=9\end{array}$ & $\begin{array}{c}\text { Control } \\
\text { group }=16.40 \pm 1.34 \\
\text { Experimental } \\
\text { group }=15.67 \pm 1.32\end{array}$ & $\begin{array}{l}\text { Func- } \\
\text { tional } \\
\text { balance }\end{array}$ & $\begin{array}{c}\text { 1. Set of motion } \\
\text { assessment-tests } \\
\text { 2. Bruininks-Oseretsky } \\
\text { Test }\end{array}$ & $\begin{array}{l}\text { An eight-week training } \\
\text { protocol of pilates and } \\
\text { Greek dance has posi- } \\
\text { tive effects on the bal- } \\
\text { ance of blind children. }\end{array}$ \\
\hline $\begin{array}{l}\text { Morelli } \\
\text { et al. } \\
\text { [32] }\end{array}$ & 6 & $\begin{array}{l}\text { An exergame to } \\
\text { improve balance in } \\
\text { children who are } \\
\text { blind }\end{array}$ & $\begin{array}{c}\text { Control } \\
\text { group }=0 \\
\text { Experimen- } \\
\text { tal group }=11\end{array}$ & 9 to 16 & $\begin{array}{l}\text { Postural } \\
\text { sway }\end{array}$ & Balance board & $\begin{array}{l}\text { Balance in the blind is } \\
\text { significantly affected. }\end{array}$ \\
\hline $\begin{array}{l}\text { Salari et } \\
\text { al. } \\
\text { [33] }\end{array}$ & 5 & $\begin{array}{l}\text { The effect of core } \\
\text { stability training } \\
\text { program on balance } \\
\text { in blind female } \\
\text { athletes }\end{array}$ & $\begin{array}{l}\text { Control } \\
\text { group=15 } \\
\text { Experimen- } \\
\text { tal group=15 }\end{array}$ & $22.40 \pm 5.35$ & $\begin{array}{l}\text { Static } \\
\text { balance } \\
\text { and } \\
\text { dynamic } \\
\text { balance }\end{array}$ & $\begin{array}{c}\text { Static balance }=\text { Single- } \\
\text { limb stand } \\
\text { Dynamic balance }=Y \\
\text { test }\end{array}$ & $\begin{array}{l}\text { Core stability exercises } \\
\text { significantly improves } \\
\text { static and dynamic bal- } \\
\text { ance in blind women. }\end{array}$ \\
\hline $\begin{array}{c}\text { Eshaghi } \\
\text { [34] }\end{array}$ & 4 & $\begin{array}{l}\text { The effect of yoga } \\
\text { exercises on balance } \\
\text { and head forward } \\
\text { complication in blind } \\
\text { male students }\end{array}$ & $\begin{array}{l}\text { Control } \\
\text { group }=8 \\
\text { Experimen- } \\
\text { tal group }=8\end{array}$ & $15.75 \pm 1.58$ & $\begin{array}{l}\text { Postural } \\
\text { sway }\end{array}$ & Biodex Stability System & $\begin{array}{c}\text { Yoga exercises improve } \\
\text { balance and treat for- } \\
\text { ward head posture. }\end{array}$ \\
\hline $\begin{array}{l}\text { Wiszomir- } \\
\text { ska et al. } \\
\text { [35] }\end{array}$ & 7 & $\begin{array}{l}\text { The impact of a } \\
\text { vestibular-stimulat- } \\
\text { ing exercise regime } \\
\text { on postural stability } \\
\text { in people with visual } \\
\text { impairment }\end{array}$ & $\begin{array}{c}\text { Group } \\
\text { without vi- } \\
\text { sual impair- } \\
\text { ment=42 } \\
\text { Group } \\
\text { with vi- } \\
\text { sual impair- } \\
\text { ment=28 }\end{array}$ & $\begin{array}{l}\text { Group without } \\
\text { visual impair- } \\
\text { ment=18 to } 20 \\
\text { Group with visual } \\
\text { impairment=The } \\
\text { average age is } 19 \\
\text { years }\end{array}$ & $\begin{array}{l}\text { Balance } \\
\text { assess- } \\
\text { ment in } \\
\text { different } \\
\text { sensory } \\
\text { condi- } \\
\text { tions }\end{array}$ & Biodex Stability System & $\begin{array}{l}\text { Exercises that involve } \\
\text { the vestibular system } \\
\text { with head and body } \\
\text { movements are helpful } \\
\text { for visually-impaired } \\
\text { people. }\end{array}$ \\
\hline $\begin{array}{l}\text { Khorami } \\
\text { Mogha- } \\
\text { dam [36] }\end{array}$ & 5 & $\begin{array}{l}\text { The effect of water } \\
\text { exercise on the bal- } \\
\text { ance and coordina- } \\
\text { tion of blind boys }\end{array}$ & $\begin{array}{l}\text { Control } \\
\text { group=10 } \\
\text { Experimen- } \\
\text { tal group=10 }\end{array}$ & 9 to 15 & $\begin{array}{l}\text { Static } \\
\text { balance, } \\
\text { dynamic } \\
\text { balance, } \\
\text { and gait } \\
\text { coordi- } \\
\text { nation }\end{array}$ & $\begin{array}{c}\text { Static balance=stork } \\
\text { test } \\
\text { Dynamic equilibrium=Y } \\
\text { test } \\
\text { Coordination=Tandem } \\
\text { gait }\end{array}$ & $\begin{array}{l}\text { Training programs in } \\
\text { water have significant } \\
\text { impacts on balance and } \\
\text { coordination in male } \\
\text { blind subjects. }\end{array}$ \\
\hline $\begin{array}{l}\text { Hosseini } \\
\text { et al. [37] }\end{array}$ & 5 & $\begin{array}{l}\text { The effect of two } \\
\text { water and physical } \\
\text { training protocols } \\
\text { on balance in blind } \\
\text { male students }\end{array}$ & $\begin{array}{l}\text { Control } \\
\text { group=12 } \\
\text { Water } \\
\text { exercise } \\
\text { group=12 } \\
\text { Exercise } \\
\text { group with } \\
\text { physio- } \\
\text { ball=12 }\end{array}$ & 7 to 12 years & $\begin{array}{l}\text { Postural } \\
\text { sway }\end{array}$ & Platform & $\begin{array}{l}\text { Both gym ball exercises } \\
\text { and in-water exercises } \\
\text { improve balance } \\
\text { indexes in the blind. } \\
\text { The results also showed } \\
\text { that the balance } \\
\text { indexes in the exercise } \\
\text { group with physioball } \\
\text { balls were higher than } \\
\text { the exercise group in } \\
\text { water. }\end{array}$ \\
\hline $\begin{array}{c}\text { Eskandari } \\
\text { [38] }\end{array}$ & 6 & $\begin{array}{l}\text { The effect of balance } \\
\text { exercises on the } \\
\text { patterned surface } \\
\text { on the balance and } \\
\text { coordination of the } \\
\text { blind }\end{array}$ & $\begin{array}{l}\text { Control } \\
\text { group=10 } \\
\text { Experimen- } \\
\text { tal group=10 }\end{array}$ & $26.13 \pm 5.2$ & $\begin{array}{l}\text { Static } \\
\text { balance } \\
\text { and } \\
\text { dynamic } \\
\text { balance }\end{array}$ & $\begin{array}{c}\text { Static balance }=\text { stork } \\
\text { test } \\
\text { Dynamic balance }=Y \\
\text { test }\end{array}$ & $\begin{array}{l}\text { Training protocols on } \\
\text { patterned surfaces } \\
\text { improve balance in the } \\
\text { blind. }\end{array}$ \\
\hline
\end{tabular}




\begin{tabular}{|c|c|c|c|c|c|c|c|}
\hline Authors & PEDro Scale & Article Title & Sample Size & Age (y) Range & $\begin{array}{c}\text { Mea- } \\
\text { sured } \\
\text { Variables }\end{array}$ & Instrument & Main Results \\
\hline $\begin{array}{l}\text { Moffa et } \\
\text { al. [39] }\end{array}$ & 5 & $\begin{array}{c}\text { Acute effect of } \\
\text { whole-body vibra- } \\
\text { tion on balance in } \\
\text { blind vs no-blind ath- } \\
\text { letes: a preliminary } \\
\text { study }\end{array}$ & $\begin{array}{l}\text { Control } \\
\text { group=10 } \\
\text { Experimen- } \\
\text { tal group=11 }\end{array}$ & $\begin{array}{c}\text { Control } \\
\text { group }=31.5 \pm 1.7 \\
\text { Experimental } \\
\text { group }=29.2 \pm 2.3\end{array}$ & $\begin{array}{l}\text { Static } \\
\text { balance }\end{array}$ & Platform & $\begin{array}{l}\text { Acute vibration has no } \\
\text { effects on balance in } \\
\text { blind or normal people. }\end{array}$ \\
\hline $\begin{array}{l}\text { Sadeghi et } \\
\text { al. [40] }\end{array}$ & 5 & $\begin{array}{l}\text { Effectiveness of } \\
\text { Core Stabilization } \\
\text { Exercises on Balance } \\
\text { and Gait speed of } \\
\text { blind students }\end{array}$ & $\begin{array}{l}\text { Control } \\
\text { group=14 } \\
\text { Experimen- } \\
\text { tal group=14 }\end{array}$ & $\begin{array}{c}\text { Control } \\
\text { group }=11.46 \pm 0.91 \\
\text { Experimental } \\
\text { group }=10.8 \pm 0.94\end{array}$ & $\begin{array}{l}\text { Static } \\
\text { balance } \\
\text { Dynamic } \\
\text { balance } \\
\text { gait } \\
\text { speed }\end{array}$ & $\begin{array}{c}\text { Static balance=foot } \\
\text { scan } \\
\text { Dynamic balance=TUG } \\
\text { Test } \\
\text { gait speed=8 meters } \\
\text { walking }\end{array}$ & $\begin{array}{l}\text { Core stability exercises } \\
\text { have significant effects } \\
\text { on the dynamic balance } \\
\text { and gait speed of the } \\
\text { blind. }\end{array}$ \\
\hline $\begin{array}{l}\text { Yousefian } \\
\text { et al. [41] }\end{array}$ & 4 & $\begin{array}{l}\text { Effect of Initial } \\
\text { Orientation and } \\
\text { mobility training, } \\
\text { and advanced }\end{array}$ & $\begin{array}{c}\text { Control } \\
\text { group }=40 \\
\text { Experimen- } \\
\text { tal group }=40\end{array}$ & 5 to 14 & $\begin{array}{l}\text { Func- } \\
\text { tional } \\
\text { skills and } \\
\text { func- } \\
\text { tional } \\
\text { balance }\end{array}$ & $\begin{array}{c}\text { Bruininks-Oseretsky } \\
\text { Test }\end{array}$ & $\begin{array}{l}\text { A 12-week training } \\
\text { protocol of movement } \\
\text { skills has significant } \\
\text { impacts on functional } \\
\text { performance and bal- } \\
\text { ance in the blind. }\end{array}$ \\
\hline $\begin{array}{l}\text { Rajabi et } \\
\text { al. [42] }\end{array}$ & 5 & $\begin{array}{l}\text { The comparison ef- } \\
\text { fects of eight weeks } \\
\text { of spark and Frenkel } \\
\text { exercises on static } \\
\text { and dynamic bal- } \\
\text { ance in the blinds }\end{array}$ & $\begin{array}{l}\text { Control } \\
\text { group }=10 \\
\text { Frank } \\
\text { group }=10 \\
\text { Spark } \\
\text { group }=10\end{array}$ & $\begin{array}{l}\text { Control group=34 } \\
\text { Frank group }=33 \\
\text { Spark group }=32\end{array}$ & $\begin{array}{l}\text { Static } \\
\text { balance } \\
\text { and } \\
\text { dynamic } \\
\text { balance }\end{array}$ & $\begin{array}{c}\text { Static balance }=\text { stork } \\
\text { test } \\
\text { Dynamic balance }=Y \\
\text { test }\end{array}$ & $\begin{array}{l}\text { Frank and spark exer- } \\
\text { cise significantly affect } \\
\text { balance in the blind. } \\
\text { Also, Frank's exercises } \\
\text { had a better effect than } \\
\text { spark's exercises. }\end{array}$ \\
\hline $\begin{array}{l}\text { Mahrokh, } \\
\text { Mogha- } \\
\text { dam et al. } \\
\text { [43] }\end{array}$ & 6 & $\begin{array}{l}\text { The Effect of Core } \\
\text { Stability Training on } \\
\text { Motor Performance } \\
\text { of Elite Goalball } \\
\text { Players }\end{array}$ & $\begin{array}{c}\text { Control } \\
\text { group=13 } \\
\text { Experimen- } \\
\text { tal group=13 }\end{array}$ & 25 to 45 & $\begin{array}{c}\text { Static } \\
\text { balance, } \\
\text { dynamic } \\
\text { balance, } \\
\text { lower } \\
\text { limb } \\
\text { function, } \\
\text { upper } \\
\text { limb } \\
\text { power, } \\
\text { and } \\
\text { motor } \\
\text { function }\end{array}$ & $\begin{array}{c}\text { Static balance=stork } \\
\text { test } \\
\text { Dynamic balance }=Y \\
\text { test }\end{array}$ & $\begin{array}{l}\text { An 8-week training } \\
\text { protocol on core } \\
\text { stability has significant } \\
\text { effects on the motor } \\
\text { performance of elite } \\
\text { goalball players }\end{array}$ \\
\hline $\begin{array}{l}\text { Sioud et } \\
\text { al. [44] }\end{array}$ & 7 & $\begin{array}{l}\text { Auditory cues } \\
\text { behind congenitally } \\
\text { blind subjects im- } \\
\text { prove their balance } \\
\text { control in bipedal } \\
\text { upright posture }\end{array}$ & $\begin{array}{l}\text { Group } \\
\text { without vi- } \\
\text { sual impair- } \\
\text { ment=11 } \\
\text { Group } \\
\text { with vi- } \\
\text { sual impair- } \\
\text { ment=11 }\end{array}$ & $\begin{array}{l}\text { Group without } \\
\text { visual impair- } \\
\text { ment }=29.2 \pm 1.2 \\
\text { Group with } \\
\text { visual impair- } \\
\text { ment }=23.3 \pm 1.4\end{array}$ & $\begin{array}{l}\text { Postural } \\
\text { sway }\end{array}$ & Force Plate & $\begin{array}{l}\text { Awareness of sounds } \\
\text { from behind increases } \\
\text { balance in the blind }\end{array}$ \\
\hline
\end{tabular}

grams to promote balance in visually impaired subjects. Nevertheless, the age and degree of visual impairment need to be taken into consideration in analyses [22].

Melzer et al. studied the effects of auditory-memory attention as a cognitive task on postural control in the blind. They reported that the blind and sighted subjects had similar postural sway in closed eyes condition. Compared with the single task, in the dual-task, the sighted subjects showed a significant decrease in postural sway, while blind subjects did not. The auditory-memory attention-demanding cognitive task does not interfere with balance control in blind subjects [23]. Ozdemir et al. studied the effects of ankle proprioception on the balance of blind and sighted people. They measured the proprioception and muscular strength of latissimus dorsi, the plantar flexion of the ankle, and postural control with open and closed eyes. Results showed that the blind had better proprioception in closed eye condition, and normal people had higher balance in open eye condition. The two groups did not significantly differ in terms of postural control. The authors concluded that ankle proprioception could not make up for poor balance in the blind [24].

Schmid et al. explored visual information as an alternative to other sensory data in static and dynamic balance. They studied 25 congenital and acquired blind subjects and compared them with normal people. Results showed that normal people experienced the same postural control as the blind, in closed eye condition, also, they had higher 
postural control in head and hip segments. On the other hand, the blind experienced higher postural control in head and hip segments, in dynamic balance. Congenital and acquired blind subjects showed similar behavior in both static and dynamic balance. The authors concluded that blindness could not be compensated for by other sensory data. This is in contrast with cross-modal plasticity in blind people and confirms the assumption that vision plays a significant role in processing and integrating other sensory information [25]. Shushtary et al. studied the frequency and latency of vestibular evoked muscular potentials, in normal and congenital blinds and found no significant differences between them. The authors reported that the formation of the neural pathway and the reflex arc of vestibular evoked muscular potentials were the same in both groups and independent of the visual system [26]. Farsi et al. manipulated sensory systems in the static balance of blind and sighted people. They stated that sway increased in both groups during static balance, but the manipulations of the vestibular system did not affect blind people and they showed no decreased balance. Also, the highest impact was observed in somatosensory manipulations. Thus, it seems that blind and sighted people use different mechanisms to apply sensory data to maintain balance [27]. Mohammadi et al. studied the performance of the somatosensory system in the postural control of blind athletes and nonathletes. They found that in cases of dominant somatosensory information, blind goalball players had better performance than other nonathlete blinds and even nonathlete sighted people. Thus, goalball and its related features positively promote the somatosensory system [28].

\section{Discussion}

The present study evaluated balance in the blind. It aimed to 1) evaluate the balance adaptation in the blind and 2) identify the effects of training protocols on balance in the blind.

\section{Balance Adaptation in the Blind}

\section{Comparing balance in the blind and sighted sub- jects}

Maintaining posture and balance is a function of the mutual processing of sensory input from different sensory systems, such as visual, vestibular, and proprioception systems. If any of these systems fails to work properly, balance is impaired [45]. Studies assert that vision also plays a key role in maintaining balance and posture and is more influential than other sensory systems [46]. Therefore, blind people are deprived of the most useful sensory system that provides the most essential information from the environment. Visual disorder leads to poor balance and postural control [47]. It is asserted by Aydog et al. Tomomitsu et al. Barati et al. Rutkowska et al. and Muursepp et al. that postural control is weaker in the blind than in their healthy counterparts [16-18, 21, 22]. It is also found that blind people rely on hip strategy to maintain balance $[9,11]$. Besides, congenital versus acquired blindness is studied in the literature. Nakata et al. stated that congenital balance has little or no effect on controlling postural sway [12]. Schmid et al. reported that congenital and acquired blindness similarly affect static and dynamic balance [25]. However, this needs further and more elaborate studies. The literature also includes studies on the intensity of visual impairment. Intensive visual impairment negatively affects balance maintenance [22].

Häkkinen et al. observed no difference between blind and sighted subjects in the muscle mass volume, maximum muscular strength, and vertical jump [19]. Giagazoglou et al. studied the isometric power of the ankle and hip muscles in blind and sighted subjects and found no significant difference [15]. Horvat et al. compared isokinetic peak force and strength in visually impaired and blind adults and reported no significant difference [13]. Moreover, Ray et al. realized that the major components of strength and balance are low in people with visual disorder [9]. Nakata et al. reported that the electromyography activity of gastrocnemius muscle in the blind was lower than in their healthy counterparts [12]. There are contrasting results on the strength of the lower trunk in the blind, also, weakness in the lower limbs may explain poor balance in these people. Mohammadi et al. showed that when somatosensory input is dominant, postural control in blind goalball players is better than in nonathlete blinds and even sighted athletes [28]. This also needs to be carefully studied.

Rutkowska et al. studied balance in the blind and found that gender played no role in balance maintenance [20]. This was inconsistent with the findings of Horvat et al. [13]. Also, Smith et al. studied the effects of gender on postural control in children aged 8 to 12 years and found that girls had better control than boys [48]. Similarly, Mickle reported that boys experienced more postural sway than girls; this was exacerbated by more difficult situations [49]. Nevertheless, boys show greater muscular strength in the lower limbs, which is essential to the balance of muscular strength. Besides, boys have higher mobility than girls. The effects of gender on balance in the blind needs to be further studied. 


\section{Effects of age on balance}

Häkkinen et al. examined the effects of age on balance in the blind before and after puberty and reported that the blind had weaker balance before puberty (9-13 years of age) than after puberty (15-18 years of age) [19]. A study on blind subjects aged 7 to 16 years revealed no difference between the age groups of 7 to 11 years and 12 to 16 years [20]. This conflicted with the earlier study that showed poorer balance in the age group of 7 to 11 years than in 12 to 16 years [22]. This is associated with the growth of sensory systems. In this regard, physiological findings indicate that visual, vestibular, and proprioception systems anatomically mature before children reach adulthood [50]. Thus, the somatosensory system grows fully before the age of 3 to 4 years [51] and reaches maturity before the age of 6 [52]. The visual growth of diplopia occurs before 4 to 5 months of age and threedimensional sharpness matures at 6 to 7 months [53], similar to that of adults. However, another study founded that children could not use proprioception for postural control before the age of 12 years [54]. At 15 to 16 years of age, sensory systems for postural control are similar to adults and adolescents [51]. Therefore, sensory systems grow by age, and the poor balance of the blind before adulthood is explained by the fact that other sensory systems (vestibular and proprioception) grow by age and have stronger roles in postural control.

Compensation of balance impairment by other sensory systems in the absence of vision

Schmid et al. showed that sighted subjects had the same postural control as the blind, in closed eye conditions [25]. Also, manipulating the vestibular system, Farsi et al. found no decreased balance and reported the highest impact for somatosensory manipulations [27]. In the case of dominant somatosensory information, blind goalball players had a better performance than other nonathlete blinds and even nonathlete sighted people [28]. Häkkinen et al. showed that sighted and blind people did not differ in balance when vision was excluded [19]. Ozdemir et al. found that ankle proprioception partially compensated imbalance in the blind [24]. Muurespp et al. reported no significant difference between the blind and sighted subjects for balance in closed eye conditions [18]. Finally, Shumway-Cook and Woollacot stated that the maintenance of postural stability is a function of integrated sensory data from visual, vestibular, and proprioception systems. Any lapse in one system is made up for by the other two [55]. Studies show that vestibular and proprioception systems are adopted in the absence of visual input. Thus, sighted and blind subjects have the same performance in such cases. However, to our surprise, only the results of Mohammadi et al. showed that proprioception was stronger in the blind than in sighted people [28]. Schmid argued that cross-modal plasticity was a controversial issue in the blind and asserted that vision plays an important role in processing and integrating other sensory inputs as well as selecting appropriate strategies for postural control [25]. Shushtary et al. showed that the neural pathway and reflex arc of vestibular evoked muscular potentials are formed similarly in both blind and sighted subjects and are independent of the visual system [26]. More studies are needed to figure out the contribution of vestibular and proprioception systems in the blind and sighted population.

\section{Effects of training protocols on balance in the} blind

Studies show that training and rehabilitation protocols decrease imbalance and can be used as a strong interventive treatment for children with visual disorder and balance dysfunction. The review of the literature showed that all training, rehabilitation, and exercise programs positively affected the balance improvement in the blind [29-44]. Mobility is one key element in these protocols because a sedentary lifestyle explains a certain aspect of imbalance in the blind population. Nevertheless, this conclusion should be made with caution, because the studies show poor quality. It is not well-documented in the literature which training protocols have the greatest effects on balance in the blind, as they ignore effect size in measuring the impacts of training and rehabilitation programs. Moreover, the reliability of tests was not validated. For postural control, the blind relied on hip rather than ankle strategy $[9,11]$. It is not clear whether measuring tests were appropriate for examining balance in them. It seems that training protocols that strengthen other sensory systems (vestibular and proprioception) are more appropriate because the blind rely on proprioception more, compared with sighted people $[11,27,28]$.

This paper performed a systematic review of existing literature but provided no qualitative analysis. Although all the articles were retrieved from authentic databases, the results of our analysis were generalized with caution. Besides, only articles in English and Persian were considered for study. Therefore, future studies are suggested to focus on offering qualitative analysis.

Our comprehensive review of the literature showed poor balance in the blind, though they showed similar performance as that of the sighted subjects, considering the vestibular and proprioception inputs. Also, balance 
in the blind improved by age, because vestibular and proprioception systems develop by age. However, the literature does not cover the effects of these systems on balance maintenance. Results also revealed that the blind mostly rely on hip strategy. On the other hand, all training protocols and exercises were found to have positive effects on balance in the blind, though there was no subtle analysis on the most influential protocols. As the blind population mostly relies on vestibular and proprioception input, it seems wise to focus on programs that enhance these sensory systems to improve balance in the blind.

\section{Ethical Considerations}

\section{Compliance with ethical guidelines}

This study was confirmed by the Ethics Committee of Guilan University.

\section{Funding}

This research did not receive any grant from funding agencies in the public, commercial, or non-profit sectors.

\section{Authors' contributions}

All authors equally contributed to preparing this article.

\section{Conflict of interest}

The authors declared no conflict of interest.

\section{References}

[1] Kamalian Lari S, Haghgoo HA, Farzad M, Hosseinzadeh S [Investigation of the validity and reliability of Balance Evaluation Systems Test (BESTest) in assessment of balance disorders in people with multiple sclerosis (Persian)]. Archives of Rehabilitation. 2018; 18(4):288-95. [DOI:10.21859/jrehab.18.4.3]

[2] Pourkhani T, Norasteh AA, Shamsi A. [Effect of ankle taping and fatigue on dynamic stability in athletes with and with out chronic ankle instability (Persian)]. Archives of Rehabilitation. 2017; 18(2):110-21. [DOI:10.21859/jrehab-1802108]

[3] Walicka-Cupryś K, Przygoda Ł, Czenczek E, Truszczyńska A, Drzał-Grabiec J, Zbigniew $\mathrm{T}$, et al. Balance assessment in hearing-impaired children. Research in Developmental Disabilities. 2014; 35(11):2728-34. [DOI:10.1016/j. ridd.2014.07.008] [PMID]

[4] Riemann BL, Lephart SM. The sensorimotor system, part I: The physiologic basis of functional joint stability. Journal of Athletic Training. 2002; 37(1):71-9. [PMID] [PMCID]
[5] Da Silva RA, Bilodeau M, Parreira RB, Teixeira DC, Amorim CF. Age-related differences in time-limit performance and force platform-based balance measures during one-leg stance. Journal of Electromyography and Kinesiology. 2013; 23(3):634-9. [DOI:10.1016/j.jelekin.2013.01.008] [PMID]

[6] Seidler RD, Mulavara AP, Bloomberg JJ, Peters BT. Individual predictors of sensorimotor adaptability. Frontiers in Systems Neuroscience. 2015; 9:100. [DOI:10.3389/fnsys.2015.00100] [PMID] [PMCID]

[7] Juodžbalienè V, Muckus K. The influence of the degree of visual impairment on psychomotor reaction and equilibrium maintenance of adolescents. Medicina (Kaunas). 2006; 42(1):49-56. [PMID]

[8] Schmidt RA, Lee TD, Winstein C, Wulf G, Zelaznik HN Motor control and learning: A behavioral emphasis. Champaign: Human Kinetics; 2018. https:/ / books.google. $\mathrm{com} /$ books?id=EvJ6DwAAQBAJ\&dq

[9] Ray CT, Horvat M, Croce R, Mason RC, Wolf SL. The impact of vision loss on postural stability and balance strategies in individuals with profound vision loss Gait \& Posture. 2008; 28(1):58-61. [DOI:10.1016/j.gaitpost.2007.09.010] [PMID]

[10] Dewar R, Love S, Johnston LM. Exercise interventions improve postural control in children with cerebral palsy: A systematic review. Developmental Medicine \& Child Neurology. 2015; 57(6):504-20. [DOI:10.1111/dmcn.12660] [PMID]

[11] Salari A, Sahebozamani M, Daneshjoo A, Karimi Afshar F. Assessment of balance recovery strategies during manipulation of somatosensory, vision, and vestibular system in healthy and blind Women. Journal of Rehabilitation Sciences \& Research. 2019; 6(3):123-9. [DOI:10.30476/ JRSR.2019.81543.1001

[12] Nakata H, Yabe K. Automatic postural response systems in individuals with congenital total blindness. Gait \& Posture 2001; 14(1):36-43. [DOI:10.1016/S0966-6362(00)00100-4]

[13] Horvat M, Ray C, Nocera J, Croce R. Comparison of isokinetic peak force and power in adults with partial and total blindness. Perceptual and Motor Skills. 2006; 103(1):231-7. [DOI:10.2466/pms.103.1.231-237] [PMID]

[14] Ray CT, Horvat M, Williams M, Blasch BB. Clinical assessment of functional movement in adults with visua impairments. Journal of Visual Impairment \& Blindness. 2007; 101(2):108-13. [DOI:10.1177/0145482X0710100205]

[15] Giagazoglou P, Amiridis IG, Zafeiridis A, Thimara M, Kouvelioti V, Kellis E. Static balance control and lower limb strength in blind and sighted women. European Journal of Applied Physiology. 2009; 107(5):571-9 [DOI:10.1007/s00421-009-1163-x] [PMID]

[16] Aydoğ E, Aydoğ ST, Cakci A, Doral MN. Dynamic postural stability in blind athletes using the biodex stability system. International Journal of Sports Medicine. 2006 27(5):415-8. [DOI:10.1055/s-2005-865777] [PMID]

[17] Tomomitsu MS, Alonso AC, Morimoto E, Bobbio TG, Greve J. Static and dynamic postural control in low-vision and normal-vision adults. Clinics. 2013; 68(4):517-21. [DOI:10.6061/clinics/2013(04)13] 
[18] Müürsepp I, Arjokesse R, Ereline J, Pääsuke M, Gapeyeva $\mathrm{H}$. Impact of visual impairment on static and dynamic postural control and habitual physical activity in children aged 10-16 years. British Journal of Visual Impairment. 2018; 36(3):227-37. https://journals.sagepub.com/doi/ full/10.1177/0264619618780918

[19] Häkkinen A, Holopainen E, Kautiainen H, Sillanpää E, Häkkinen K. Neuromuscular function and balance of prepubertal and pubertal blind and sighted boys. Acta Paediatrica. 2006 95(10):1277-83. [DOI:10.1080/08035250600573144] [PMID]

[20] Rutkowska I, Skowroński W. A comparison of body balance of blind children aged 7-16 years in sex and age categories. Studies in Physical Culture \& Tourism. 2007; 14(suppl 2007):287-92. https://www.semanticscholar.org/ paper/A-comparison-of-body-balance-of-blind-childrenaged-Rutkowska-Skowro\%C5\%84ski/6f5ba85f7d1143a56d718c8da7d42780b2b90e69

[21] Ahmadi Barati S, Ahmadi Barati A, Ghaeini S, Ahanjan S, Helbi F. [The growth status of balance capabilities of low vision children, blind and their healthy counterparts (Persian)]. 2013; 3(9):69-77. https://www.sid.ir/fa/journal/ ViewPaper.aspx?ID=204931

[22] Rutkowska I, Bednarczuk G, Molik B, Morgulec-Adamowicz N, Marszałek J, Kaźmierska-Kowalewska K, et al. Balance functional assessment in people with visual impairment. Journal of Human Kinetics. 2015; 48(1):99-109. [DOI:10.1515/hukin-2015-0096] [PMID] [PMCID]

[23] Melzer I, Damry E, Landau A, Yagev R. The influence of an auditory-memory attention-demanding task on postural control in blind persons. Clinical Biomechanics. 2011; 26(4):35862. [DOI:10.1016/j.clinbiomech.2010.11.008] [PMID]

[24] Ozdemir RA, Pourmoghaddam A, Paloski WH. Sensorimotor posture control in the blind: Superior ankle proprioceptive acuity does not compensate for vision loss. Gait \& Posture. 2013; 38(4):603-8. [DOI:10.1016/j.gaitpost.2013.02.003] [PMID]

[25] Schmid M, Nardone A, De Nunzio AM, Schmid M, Schieppati $\mathrm{M}$. Equilibrium during static and dynamic tasks in blind subjects: No evidence of cross-modal plasticity. Brain. 2007; 130(Pt 8):2097-107 [DOI:10.1093/brain/awm157] [PMID]

[26] Shomeil Shushtary S, Adel Ghahraman M, Sedaie M, Talebian S, Jalaie S, Tavakoli M. [Vestibular evoked myogenic potential in congenitally blind patients versus normal subjects (Persian)]. Audiology. 2011; 20(1):96-106. https://aud. tums.ac.ir/article-1-86-en.html

[27] Farsi A, Abdoli B, Najafi K. [Dual task effects in sensory systems interference condition on blind and sighted persons balance (Persian)]. Motor Behavior. 2014; 6(15):15-28. https://mbj.ssrc.ac.ir/article_509.html

[28] Mohammadi F, Bayati M, Abbasi H, Allafan N. Better functioning of the somatosensory system in postural control of blind athletes compared to non-athletes. Scientific Journal of Rehabilitation Medicine (SJRM). 2019; 8(3):179-87. http:// medrehab.sbmu.ac.ir/article_1100692_en.html

[29] Jazi SD, Purrajabi F, Movahedi A, Jalali S. Effect of selected balance exercises on the dynamic balance of children with visual impairments. Journal of Visual Impairment \& Blindness. 2012; 106(8):466-74. [DOI:10.1177/0145482X1210600803]

[30] Sajjadi Manizani N. [The effect of four weeks of treadmill training on static and dynamic balance of the blind and visu- ally impaired (Persian)] [MSc. thesis]. Tehran: Islamic Azad University of Tehran Branch Markaz; 2012. https:/ /ganj.irandoc.ac.ir/\#/articles/164eb1baedf8ff95e5e3a59cb1e2bad4

[31] Mavrovouniotis FI, Papaioannou CS, Argiriadou EA, Mountakis CM, Konstantinakos PD, Pikoula IT, et al. The effect of a combined training program with Greek dances and Pilates on the balance of blind children. Journal of Physical Education and Sport. 2013; 13(1):91-100. https://efsupit.ro/images/stories/ art_16.GreekDances-PilatesBlindChildrenBalance-final.pdf

[32] Morelli T, Lieberman L, Foley J, Folmer E. An exergame to improve balance in children who are blind. Paper presented at: Conference: Proceedings of the $9^{\text {th }}$ International Conference on the Foundations of Digital Games. 3-7 April 2014. Spain: Caribbean. https://www.researchgate.net/publication/263010018_An_Exergame_to_Improve_Balance_in_ Children_who_are_Blind

[33] Salari A, Sahebalzamani M, Daneshmandi H. [The effect of core stability training program on balance in blind female athletes (Persian)]. Journal of Kerman University of Medical Sciences. 2013; 20(6):585-95. http://jkmu.kmu.ac.ir/article_16358.html

[34] Eshaghi S. [The effect of yoga exercises on balance and head forward complication in blind male students (Persian)] [MA. thesis]. Mashhad: Ferdowsi University of Mashhad. https://elmnet.ir/article/10796714-51811

[35] Wiszomirska I, Kaczmarczyk K, Błażkiewicz M, Wit A. The impact of a vestibular-stimulating exercise regime on postural stability in people with visual impairment. BioMed Research International. 2015; 2015:136969. [DOI:10.1155/2015/136969] [PMID] [PMCID]

[36] Khorami Moghadam M. [The effect of water exercise on the balance and coordination of blind boys (Persian)]. [MA. thesis]. Arak: Arak University. https://elmnet.ir/article/10940240-82904/

[37] Hosseini SM. [Comparison of the effect of two water and physiobial training protocols on balance in blind male students (Persian)] [MA. thesis]. Mashhad: Ferdowsi University of Mashhad. http://library.um.ac.ir/index. php?option $=$ com_lib\&view $=$ docinfo\&type $=2 \& D o c I D=5995$ 6\&lang $=\mathrm{fa}$

[38] Eskandari H. [The effect of two water and physiobial training protocols on balance in blind male students (Persian)]. [MA. thesis]. Arak: Arak University. https://elmnet.ir/article/10842642-11474/

[39] Moffa S, Iuliano E, Di Cagno A, Pistone EM, Fiorilli G, Calcagno $G$. Acute effect of whole body vibration on balance in blind vs. no-blind athletes: A preliminary study. Sport Sciences for Health. 2017; 13(2):323-9. [DOI:10.1007/s11332-017-0361-x]

[40] Sadeghi S, Mahdavinezhad R, Kamali A. [Effectiveness of Core Stabilization Exercises on Balance and Gait speed of blind students (Persian)]. Journal of Research in Sport Rehabilitation. 2016; 4(7):21-30. [DOI:10.22084/RSR.2016.1590]

[41] Yousefian M, Yousefi S. Najafi Fard T, Ahmadi F. [Effect of Initial Orientation and mobility training, and advanced (Persian)]. Shenakht Journal of Psychology \& Psychiatry. 2016; 3(1):102-12. http:/ / shenakht.muk.ac.ir/article-1-203-en.html

[42] Rajabi S, Goodarzi B, Mazidi M. [The comparison effects of eight weeks spark and frenkel exercises on static and dynam- 
ic balance in the blinds (Persian)]. Hormozgan Medical Journal. 2017; 20(6):373-80. [DOI:10.18869/acadpub.hmj.20.6.401]

[43] Mahrokh Moghadam A, Zarei M, Mohammadi F. [The effect of core stability training on motor performance of elite goalball players (Persian)]. Sport Medicine Studies. 2018; 10(23): 47-60. [DOI:10.22089/SMJ.2017.3605.1196]

[44] Sioud R, Khalifa R, Houel N. Auditory cues behind congenitally blind subjects improve their balance control in bipedal upright posture. Gait \& Posture. 2019; 70:175-8. [DOI:10.1016/j.gaitpost.2019.03.004] [PMID]

[45] Norasteh AA, Zarei H. Studying balance in deaf people: A systematic review study. Archives of Rehabilitation. 2019; 20(1):2-15. [DOI:10.32598/rj.20.1.2]

[46] Berencsi A, Ishihara M, Imanaka K. The functional role of central and peripheral vision in the control of posture. Human Movement Science. 2005; 24(5-6):689-709. [DOI:10.1016/j.humov.2005.10.014] [PMID]

[47] Fortin M, Voss P, Lassonde M, Lepore F. Sensory loss and brain reorganization. Medicine Sciences. 2007; 23(11):917-22. [DOI:10.1051/medsci/20072311917] [PMID]

[48] Smith A, Ulmer F, Wong D. Gender differences in postural stability among children. Journal of Human Kinetics. 2012; 33(1):25-32. [DOI:10.2478/v10078-012-0041-5] [PMID] [PMCID]

[49] Mickle KJ, Munro BJ, Steele JR. Gender and age affect balance performance in primary school-aged children. Journal of Science and Medicine in Sport. 2011; 14(3):243-8 [DOI:10.1016/j.jsams.2010.11.002] [PMID]

[50] Peterson ML, Christou E, Rosengren KS. Children achieve adult-like sensory integration during stance at 12-yearsold. Gait \& Posture. 2006; 23(4):455-63. [DOI:10.1016/j.gaitpost.2005.05.003] [PMID]

[51] Steindl R, Kunz K, Schrott-Fischer A, Scholtz A. Effect of age and sex on maturation of sensory systems and balance control. Developmental Medicine and Child Neurology. 2006; 48(6):477-82. [DOI:10.1111/j.1469-8749.2006.tb01299.x] [PMID]

[52] Fitzpatrick R, McCloskey D. Proprioceptive, visual and vestibular thresholds for the perception of sway during standing in humans. The Journal of Physiology. 1994; 478(1):173-86. [DOI:10.1113/jphysiol.1994.sp020240] [PMID] [PMCID]

[53] Neuringer M, Jeffrey BG. Visual development: Neural basis and new assessment methods. The Journal of Pediatrics. 2003; 143(4):87-95. [DOI:10.1067/S0022-3476(03)00406-2]

[54] Rinaldi NM, Polastri PF, Barela JA. Age-related changes in postural control sensory reweighting. Neuroscience Letters. 2009; 467(3):225-9. [DOI:10.1016/j.neulet.2009.10.042] [PMID]

[55] Shumway-Cook A, Woollacott MH. Motor control: Translating research into clinical practice. Philadelphia: Lippincott Williams \& Wilkins; 2007. https:/ /books.google.com/ books?id=BJcL3enz3xMC\&dq 